\title{
Análise preliminar de riscos: estudo de caso em um laboratório de prótese odontológica
}

\author{
RESUMO
}

Higor Guilherme Vilas Boas higorgvb@gmail.com

Universidade Estadual de Maringá (UEM) Maringá, Paraná, Brasil

Ana Carla Fernandes Gasques acfgasques2@uem.br Universidade Estadual de Maringá (UEM), Maringá, Paraná, Brasil

Maria de Lourdes Santiago Luz mlsluz@uem.br

Universidade Estadual de Maringá (UEM), Maringá, Paraná, Brasil

\begin{abstract}
A Segurança e Saúde no Trabalho é de fundamental importância para reduzir acidentes dentro das indústrias e dos ambientes de trabalho no geral, estando hoje difundida através de legislações e como indicadores de desempenho. Contudo, além de reduzir acidentes, é importante saber quais as causas e os riscos relacionados a ocorrência destes, identificando e analisando-os através de ferramentas específicas. Com isto, é possível encontrar soluções para redução ou evitar tais situações. O presente trabalho teve por objetivo avaliar os riscos ocupacionais em um Laboratório de Prótese Odontológica. Para tal, foram utilizadas ferramentas como a Análise Preliminar de Riscos e o método OWAS juntamente com a avaliação do layout da empresa e de seu processo produtivo para identificar os riscos ocupacionais e elaborar um Mapa de Riscos. A partir do desenvolvimento da pesquisa, foi possível constatar que os riscos ocupacionais estão presentes no ambiente de trabalho, sendo que, o risco de maior recorrência é o ergonômico. Por fim, é possível concluir que ao avaliar os riscos, apresenta-los à empresa e posteriormente, propor meios de reduzi-los, é de grande importância para empresa e traz benefícios ao colaborador.
\end{abstract}

PALAVRAS-CHAVE: Riscos ocupacionais. Identificação e análise de riscos. Ambiente de trabalho. 


\section{INTRODUÇÃO}

A área de Segurança e Saúde no Trabalho (SST) tem como objetivo a proteção e prevenção aos riscos e danos à vida e à saúde dos trabalhadores, por meio de políticas públicas e de ações de fiscalização, os riscos à saúde do trabalhador estão presentes nos diversos tipos de atividades realizadas nas empresas, independente do ramo que estão envolvidas (BRASIL, 2015). Para Rodrigues (2006) o risco é onde pode haver dano causado pelo exercício do trabalho, e para qualifica-lo deve-se avaliar a probabilidade de ocorrência juntamente à sua gravidade.

Segundo Mattos e Másculo (2011) o conceito de risco pode ser visto tanto do aspecto quantitativo, avaliando a probabilidade da ocorrência de um acidente, quanto do aspecto qualitativo, indicando o perigo relacionado a tal fato. Nos dias atuais, as políticas de conscientização sobre riscos ocupacionais são fortemente difundidas nas grandes indústrias, principalmente por haverem leis trabalhistas e órgãos regulamentadores que fazem com que essas indústrias mantenham políticas eficientes de segurança e saúde dos trabalhadores (BRASIL, 2011).

Contudo, em Pequenas e Microempresas essa situação não ocorre da mesma forma, visto que a cobrança é menor e também pelo fato de haver pouco ou nenhum conhecimento da parte dos empregadores e principalmente dos empregados (BRASIL, 2010). Neste contexto, é de grande importância analisar e avaliar a situação destas microempresas em relação a saúde e segurança do trabalhador, tendo como base as normas regulamentares e utilizando de ferramentas que avaliem os riscos ocupacionais auxiliando nas tomadas de decisões (BRASIL, 2015).

Além de obter resultados e apresenta-los ao empregador, deve-se mostrar e fornecer conhecimentos aos funcionários sobre a situação em que se encontram, para que estes trabalhadores saibam a importância de se controlar esses riscos e melhorar o ambiente de trabalho (MÁSCULO; VIDAL, 2011). Diante disso, o referente trabalho, trata-se de um estudo que visa avaliar os riscos ocupacionais em um Laboratório de Prótese Odontológica situado em Maringá, cujos principais produtos são próteses em metalocerâmica e próteses em resina. Com a crescente demanda de produtos torna-se necessário a aquisição de novos equipamentos e contratação de novos funcionários, porém, a falta de organização do meio de trabalho, pode oferecer riscos aos trabalhadores.

Sendo assim, este trabalho tem por objetivo geral identificar e analisar os possíveis riscos do ambiente de trabalho. Como objetivos específicos têm-se a caracterização da empresa, aplicação de um questionário de percepção aos colaboradores, realização da Análise Preliminar de Riscos, elaboração do mapa de riscos e por fim propor medidas para as causas dos riscos.

\section{REVISÃO DE LITERATURA}

A Segurança e Saúde no Trabalho (SST) trata da prevenção e proteção dos riscos e danos à vida e à saúde dos trabalhadores, a partir de políticas e ações de fiscalização (BRASIL, 2015). A primeira lei de proteção aos trabalhadores surgiu em 1802 na Inglaterra, denominada "Lei de Moral e Saúde dos Aprendizes", estabelecia o limite de trabalho para 12 horas e proibia a maioria dos horários 
noturnos além de obrigar os empregadores a ventilar as instalações e lavar as paredes das fábricas duas vezes por ano (FREITAS, 2016).

No Brasil, em relação à SST, é de responsabilidade dos ministérios governamentais a implementação das Política Nacional de Segurança e Saúde do Trabalhador (PNSST). Essas permanecem distribuídas conforme a abrangência de cada órgão, no qual foram atribuídas, a normatização ao Ministério do Trabalho e Emprego (MTE) e ao Ministério da Saúde (MS), sendo que, a fiscalização dos ambientes de trabalho cabe respeito também ao MTE assim como a maior parte das questões de promoção, prevenção e vigilância à SST. Já as questões relacionadas à assistência, reinserção e reabilitação ficaram a cargo do Ministério da Previdência Social (MPS) (CHAGAS; SALIM; SERVO, 2012).

A PNSST tem como principais objetivos a universalidade, a integralidade, o diálogo social e a precedência das ações de promoção, proteção e prevenção sobre as de assistência e reabilitação. Os objetivos propostos são a promoção da saúde e a melhoria da qualidade de vida do trabalhador e a prevenção de acidentes e danos à saúde relacionados ao trabalho ou que decorram no curso dele (DIAS; SILVA, 2013).

\section{ACIDENTES DE TRABALHO E RISCOS OCUPACIONAIS}

O conceito legal de acidente de trabalho segundo a Lei №. 6367/76 refere-se ao que acontece pelo exercício do trabalho a serviço da empresa ou pelo exercício do trabalho dos assegurados previdenciários, provocando lesão corporal ou perturbação funcional que cause morte ou a perda ou redução, permanente ou temporária para o trabalho. São considerados pela lei como acidentes de trabalho: doença profissional adquirida em exercício do trabalho, doença do trabalho adquirida em função das condições de trabalho, acidente ligado ao trabalho mesmo que não seja a causa única, acidente sofrido em local e horário de trabalho, doença proveniente de contaminação acidental no exercício do trabalho, acidente sofrido a serviço da empresa fora do local e horário de trabalho (BRASIL, 1976).

No dia a dia das grandes empresas os trabalhadores estão sujeitos aos riscos de trabalho, esses riscos são todos os fatores que colocam o trabalhador em perigo e afetam sua integridade física ou moral. São riscos que podem gerar acidentes: arranjo físico deficiente, máquinas e equipamentos sem proteção, ferramentas inadequadas ou defeituosas, eletricidade, incêndio ou explosão, armazenamento inadequado, animais peçonhentos, entre outros (PORTO, 2008).

Conforme a Norma Regulamentadora 09, que trata sobre o Programa de Prevenção de Riscos Ambientais, são considerados riscos ambientais aqueles existentes nos ambientes de trabalho que, em função de sua natureza, concentração ou intensidade e tempo de exposição, que são capazes de causar danos à saúde do trabalhador. Tais riscos podem ser causados por agentes físicos, químicos e biológicos (BRASIL, 2017).

Além dos riscos citados acima, o colaborador em seu ambiente de trabalho pode estar exposto ao risco de acidentes ou risco mecânico, o qual é abordado nas Normas Regulamentadoras 04, 05 e 06, como também riscos ergonômicos conforme aborda a Norma Regulamentadora 17. 
Entende-se como riscos químicos aqueles causados por poeiras, fumos, névoas, neblinas, gases, vapores, e produtos químicos em geral. O contato do trabalhador com esses produtos pode causar efeitos patológicos, tais como câncer, mutações, doenças sistêmicas, entre outros (MATTOS; MÁSCULO, 2011).

A NR 09 considera agentes químicos aqueles em que o trabalhador, pela natureza da atividade de exposição, possa ter contato e sejam absorvidos pelo organismo através da pele ou por ingestão, sendo estes, as substâncias, compostos ou produtos que possam penetrar no organismo pela via respiratória, nas formas de poeiras, fumos, névoas, neblinas, gases ou vapores (BRASIL, 2017).

\section{Riscos Físicos}

Entende-se por riscos físicos aqueles relacionados as características do meio ambiente, que podem causar danos àqueles contidos em tal meio e que tem como causa ruídos, vibrações, temperatura, radiações, calor, pressões anormais e umidade. Estes riscos podem se agravar dependendo da concentração e do tempo de exposição no ambiente de trabalho (MATTOS; MÁSCULO, 2011).

A NR 09 considera como agentes físicos as diversas formas de energia a que os trabalhadores possam estar expostos, tais como: ruído, vibrações, pressões anormais, temperaturas extremas, radiações ionizantes, radiações não ionizantes, bem como o infrassom e o ultrassom (BRASIL, 2017).

\section{Riscos Biológicos}

São aqueles originados da exposição ocupacional a agentes biológicos tais como vírus, bactérias, protozoários, fungos, parasitas e costumam estar presentes, principalmente, em atividades realizadas em hospitais, limpeza pública e laboratórios. Em contato com o homem, estes agentes podem provocar inúmeras doenças. Como principais causas deste tipo de risco, pode-se citar a falta de higienização dos locais de trabalho (MATTOS; MÁSCULO, 2011).

A Norma Regulamentadora 09, considera como agentes dos riscos biológicos as bactérias, fungos, bacilos, parasitas, protozoários, vírus, entre outros (BRASIL, 2017).

\section{Riscos Ergonômicos}

Risco ergonômico refere-se àqueles derivados de condições de trabalho no efetivo da atividade como, esforço físico intenso, posturas inadequadas, imposição de ritmos excessivos, jornadas de trabalho prolongadas, monotonia e repetitividade (MÁSCULO; VIDAL, 2011).

Devido à frequência e gravidade destes riscos nos ambientes de trabalho, exige-se que estes ambientes se adaptem ao homem, conforme descrito na NR17, que estabelece parâmetros que permitem a adaptação das condições de trabalho às características psicofisiológicas dos trabalhadores, proporcionando 
máximo conforto, segurança e desempenho eficiente além de bem estar físico e psicológico (BRASIL, 2007).

\section{Riscos Mecânicos ou de Acidentes}

Riscos mecânicos ou de acidentes são aqueles ocorridos em função das condições impróprias do ambiente de trabalho, que podem causar, direta ou indiretamente, esmagamento, corte por cisalhamento, decepamento, choque, perfuração (MATTOS; MÁSCULO, 2011). Podem ser causados por materiais cortantes, aquecidos, perfuro cortantes, objetos energizados ou em movimento, consequentes de arranjos físicos inadequados, máquinas e equipamentos sem proteção, ferramentas inadequadas ou defeituosas, iluminação inadequada, dentre outros.

É definido por lei como, ocorrência não planejada que resulte em danos à saúde e integridade física do trabalhador (BRASIL, 2011).

\section{MÉTODOS DE IDENTIFICAÇÃO E ANÁLISE DE RISCOS}

Os métodos de identificação e análise de riscos consistem de técnicas que, quando aplicadas corretamente no ambiente corporativo, irão avaliar os riscos inerentes aos processos e auxiliar na tomada de decisões que permitam impor medidas que evitem ou reduzam estes problemas (MÁSCULO; VIDAL, 2011). Pode-se citar: análise What-if, Hazop, Matriz de Riscos, FMEA e APR como métodos de análise de riscos e, no que diz respeito ao risco ergonômico, um dos métodos é o OWAS.

A análise "What-If?" é um tipo de técnica especulativa feita a partir de reuniões entre duas equipes tentando responder o que ocorreria diante da ocorrência de falhas e as equipes questionadoras devem ser familiarizadas com o sistema a ser analisado. Os questionamentos devem ser embasados nos procedimentos, instalações e processos da situação analisada, e deve-se formulálos com antecedência para que os mesmos possam guiar a discussão (MATTOS; MÁSCULO; 2011). O Hazard and Operability Studies (HAZOP) é um tipo de técnica especulativa feita a partir de reuniões entre duas equipes tentando responder o que ocorreria diante da ocorrência de falhas e as equipes questionadoras devem ser familiarizadas com o sistema a ser analisado. Os questionamentos devem ser embasados nos procedimentos, instalações e processos da situação analisada, e deve-se formulá-los com antecedência para que os mesmos possam guiar a discussão (MATTOS; MÁSCULO; 2011).

A matriz de riscos é um método de análise elaborado através de duas variáveis, severidade e frequência, podendo ser separada em regiões que caracterizam os níveis de risco avaliados. Os níveis são definidos conforme a variação dos processos avaliados, produtos operacionalizados e do perfil do risco gestor (BERKENBROCK; BASSANI; 2010).

A Análise de Modos e Efeito de Falhas (FMEA) é utilizado para analisar a fonte dos riscos. O método é empregado no estudo de como as falhas de componentes específicos de um equipamento ou subsistema do processo se distribuem ao longo do sistema e, avaliando estas falhas é possível estabelecer e 
determinar as taxas e efeitos das mesmas, além de estipular melhorias nos equipamentos e sistemas que aumentem sua confiabilidade (MATTOS; MÁSCULO; 2011).

A Análise Preliminar de Riscos (APR) é uma ferramenta usada para realizar a análise qualitativa em projetos que estão na fase de concepção ou desenvolvimento, ou em atividades cuja experiência em riscos nas suas operações é deficiente (AMARILLA; CATAI; HOLLEBEN, 2012). A APR é uma análise qualitativa, realizada na fase de projeto e desenvolvimento de qualquer processo, produto ou sistema. É de suma importância na investigação de novos sistemas de alta inovação ou que sejam pouco conhecidos. Outra forma de utilização é como ferramenta de revisão geral de segurança em sistemas em operação, a qual irá revelar aspectos que não foram observados anteriormente (MATTOS; MÁSCULO; 2011).

Sua aplicação é dada pelo diagnóstico do local de trabalho onde, classificando-se a severidade dos possíveis acidentes do processo produtivo, deve-se avaliar a frequência em que tais acidentes podem ocorrer e, cruzando estes dados, é possível obter o índice de ocorrência do risco e por último se estabelece medidas de controle para os riscos identificados (CESARO, 2013). A matriz classifica os riscos através da probabilidade ocorrência, que pode ser: (3) Alta, (2) Média e (1) Baixa, e a gravidade do risco, sendo: (3) Alta, (2) Média, (1) Baixa, como pode ser visto na Figura 1.

Figura 1 - Metodologia para Avaliação de Riscos

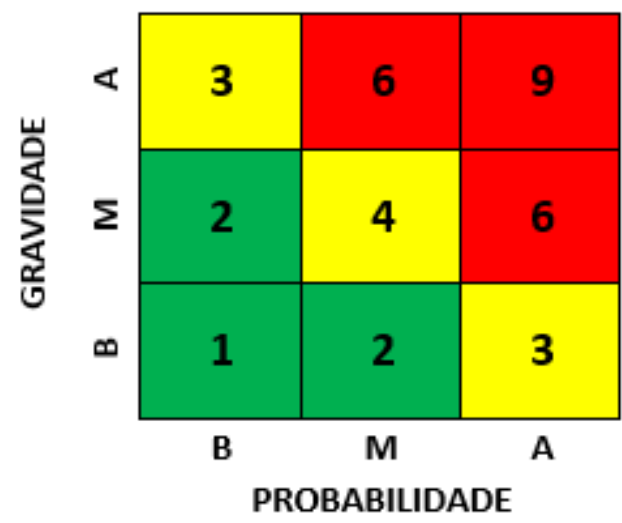

Fonte: Mattos e Másculo (2011).

Sendo que, uma probabilidade de ocorrência alta é aquela em que se espera que ocorra, uma probabilidade média, é aquela que é provável que ocorra, e a baixa é improvável que ocorra. Já em relação a gravidade, se for alta significa que pode ocorrer morte e lesões incapacitantes, média seria a que pode causar doenças ocupacionais e lesões menores, e uma gravidade baixa seria aquela que pode ocasionar danos materiais e prejuízo ao processo (MATTOS; MÁSCULO; 2011).

No caso dos riscos ergonômicos, é importante citar o sistema Ovako Working Posture Analysing System (OWAS), sistema de análise de postura de trabalho desenvolvido entre 1974 e 1978, tem como objetivo a identificação de posturas corporais prejudiciais durante a realização das atividades. O método avalia diferentes combinações de posturas típicas de dorso, braços e pernas, e com 
base nestas informações, classifica as atividades em 4 classes diferentes conforme o nível de gravidade de cada uma (MÁSCULO, VIDAL, 2011). Na Figura 2 é possível verificar exemplos de posturas típicas do método OWAS.

Figura 2 - Registro de Posturas do Método OWAS

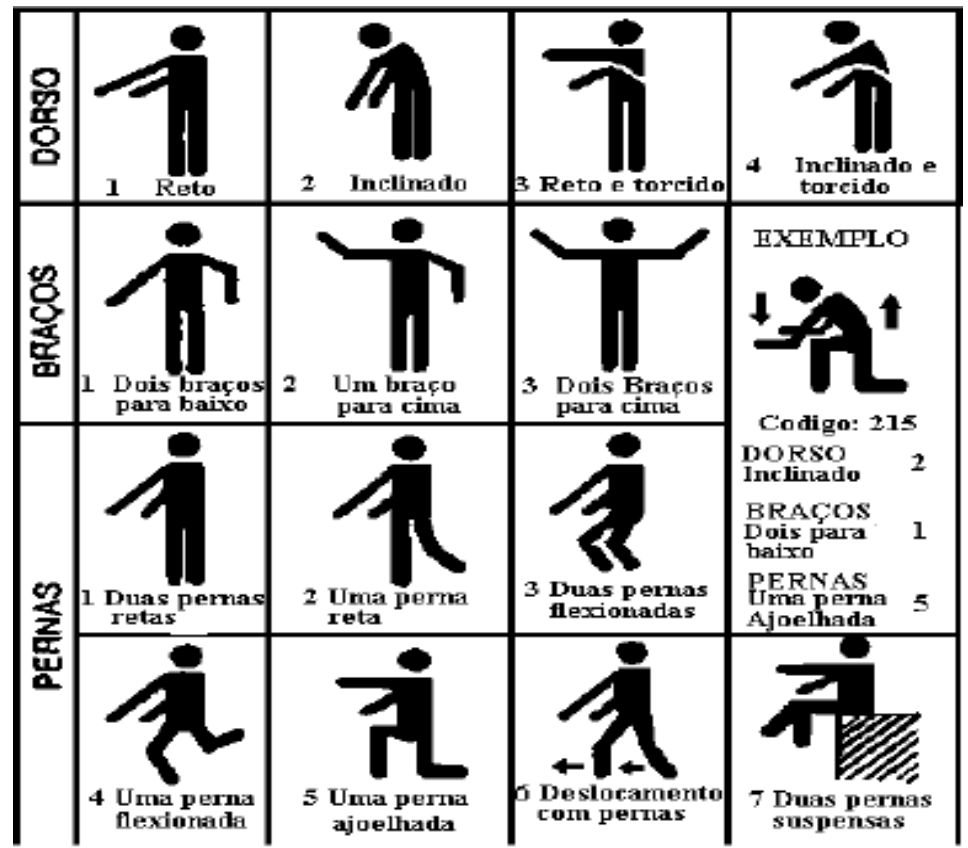

Fonte: Ilda (2005).

Como visto na Figura 2, o método consiste no registro das posturas em um código de três dígitos, que representam dorso, braços e pernas respectivamente. Este registro é feito a partir da observação da frequência e o tempo de realização das atividades, e com isso determina-se o efeito do sistema músculo-esquelético analisando-se as posturas combinadas entre costas, braços, pernas e forças exercidas (SILVA, 2010). Segundo Ilda (2005), a partir destas análises, as posturas são classificadas em 4 categorias conforme o desconforto que cada uma apresenta, sendo:

Classe 1 - postura normal que dispensa cuidados imediatos; Classe 2 postura que deve ser verificada na próxima avaliação dos métodos de trabalho; Classe 3 - postura que merece atenção a curto prazo; e, Classe 4 - postura que merece atenção imediata.

\section{MAPA DE RISCOS}

O mapa de riscos nada mais é do que a representação gráfica baseada no layout da instituição, com os riscos presentes no local. Os riscos já citados anteriormente, são divididos por cores, onde cada cor representa um tipo de risco, e cada cor será subdividida em círculos no qual o diâmetro varia conforme a gravidade do risco que representa (PORTO, 2008).

Ao elaborar um mapa de riscos, estes podem ser agrupados de acordo com seu tipo (físico, químico, biológico, de acidente e ergonômico) sendo, identificados por colorações diferentes conforme apresentado na Figura 3. 
Figura 3 - Classificação dos riscos para elaboração de Mapa de Riscos

\begin{tabular}{|c|c|c|c|}
\hline GRUPO & RISCOS & $\begin{array}{c}\text { COR } \\
\text { DE } \\
\text { IDENTIFICAC,ĀO }\end{array}$ & EXEMPLOS \\
\hline 01 & Físicos & Verde & $\begin{array}{l}\text { Ruído, calor, frio, pressöes, } \\
\text { umidade, radiaçöes ionizantes } \\
\text { e não ionizantes, vibraçöes etc. }\end{array}$ \\
\hline 02 & Químicos & Vermetho & $\begin{array}{l}\text { Poeiras, fumos, gases, } \\
\text { vapores, névoas, neblinas etc. }\end{array}$ \\
\hline 03 & Biológicos & Marron & $\begin{array}{c}\text { Fungos, vírus, parasitas, } \\
\text { bactérias, protozoários. } \\
\text { insetos etc. }\end{array}$ \\
\hline 04 & Ergonômicos & Amarela & $\begin{array}{l}\text { Levantamento e transporte } \\
\text { manual de peso, monotonia, } \\
\text { repetividade, responsabilidade. } \\
\text { ritmo excessivo, posturas } \\
\text { inadequadas de trabalho. } \\
\text { trabalho em turnos etc. }\end{array}$ \\
\hline 05 & Acidentes & Azul & $\begin{array}{l}\text { Arranjo físico inadequado, } \\
\text { iluminação inadequada, } \\
\text { incêndio e explosão, } \\
\text { eletricidade, maquinas e } \\
\text { equipamentos sem proteça, } \\
\text { queda e animais peçonhentos. }\end{array}$ \\
\hline
\end{tabular}

Fonte: Mattos (1993).

Conforme visto na Figura 3, cada agrupamento de risco é representado por uma cor diferente, facilitando a compreensão do mapa. Além disso, os riscos são diferenciados de acordo com o tamanho do símbolo de representação (Figura 4). Um mapa de risco pode conter um ou mais riscos representados, conforme o tipo de ambiente de trabalho.

Figura 4 - Classificação e Representação dos riscos quanto a sua intensidade

\begin{tabular}{|c|c|c|}
\hline SIMBOLO & PROPORÇÃo & TIPO DE RISCOS \\
\hline & 4 & Grande \\
\hline & 2 & Médio \\
\hline & 1 & Pequeno \\
\hline
\end{tabular}

Fonte: Mattos (1993).

A partir da Figura 4, constata-se que são três tamanhos (grande, médio e pequeno) a ser representado de acordo com a intensidade. Segundo a Norma regulamentadora NR 05 a identificação dos riscos e elaboração do mapa de riscos é de responsabilidade da Comissão Interna de Prevenção de Acidentes, o qual deve ser elaborado segundo os critérios estabelecidos na referida norma.

A elaboração do Mapa de Riscos deve ser realizada através das etapas do conhecimento e descrição do processo, identificação dos riscos, identificação das 
medidas preventivas, identificação dos indicadores de saúde, análise das causas mais frequentes de ausência do trabalho, levantamento de análises já realizadas e elaboração do mapa de riscos sobre o layout da empresa. No mapa deve constar o círculo indicando a cor referente ao risco e sua intensidade e o número de trabalhadores expostos ao risco (BRASIL, 2011).

\section{METODOLOGIA ADOTADA}

Do ponto de vista de sua natureza, este artigo caracteriza-se como sendo uma pesquisa aplicada no qual foram gerados conhecimentos para aplicação prática e solução de problemas específicos. Em relação à sua abordagem, classifica-se como pesquisa qualitativa no qual os dados foram levantados no ambiente de trabalho com foco no processo produtivo (GIL, 2010).

Já do ponto de vista de seus objetivos, caracteriza-se como uma pesquisa descritiva no qual foi descrito o processo produtivo avaliando-se os riscos encontrados no mesmo utilizando-se de técnicas e ferramentas específicas para o levantamento dos dados. Do ponto de vista dos procedimentos técnicos, o presente trabalho trata-se de um estudo de caso, no qual foi feito um estudo profundo e detalhado do ambiente de trabalho, permitindo obter conhecimento sobre os riscos em que os trabalhadores estão expostos e que podem interferir no processo, e a partir disto, sugeriu-se métodos de controle e melhoria para o problema referido (GIL, 2010).

No estudo de caso foram realizadas visitas para caracterização da empresa e com as informações obtidas foi realizado o mapeamento do processo produtivo. Aplicou-se um questionário de percepção aos colaboradores sobre a duração de suas atividades, quais delas trazem algum desconforto e qual o nível de cansaço (baixo; médio; alto) ao final do dia. O questionário foi composto por 5 questões abertas a fim de identificar o perfil do colaborador (idade, sexo, setor, tempo de trabalho e função) bem como uma tabela a ser completada, contendo informações sobre atividade desenvolvida, tempo de execução, posição e nível de cansaço. Ao fim, o colaborador era questionado sobre a parte do corpo com maior desconforto.

A partir do levantamento destes dados, juntamente com a análise visual do processo, foi possível identificar os riscos recorrentes de cada atividade e que possam trazer danos à saúde do colaborador. Para isto, realizou-se sua análise através de formulários da Análise Preliminar de Riscos, onde, foi possível identificar a causa dos riscos e o efeito que tais riscos trazem aos colaboradores. Também foi possível avaliar a probabilidade de ocorrência ou frequência de cada risco, através da matriz de classificação de riscos (Figura 1) e por fim foram levantadas possíveis medidas de prevenção aos riscos inerentes.

A análise dos esforços biomecânicos relacionados aos riscos ergonômicos foi desenvolvida a partir da aplicação do método OWAS para classificação das posturas de trabalho, conforme o nível de esforço juntamente com o auxílio do software Ergolândia que, avalia a postura das costas, braços e pernas, além do esforço realizado na atividade e com isto, sugere uma ação a ser tomada para tal situação. As categorias de posturas são divididas em: Classe 1, onde a postura é normal, Classe 2 , onde merece atenção à médio prazo, Classe 3 , merece atenção a curto prazo e Classe 4 a qual merece atenção imediata (Figura 5). 
Figura 5 - Avaliação das Categorias de Ação do Método OWAS

\begin{tabular}{|c|c|c|c|c|c|c|c|c|c|c|c|c|c|c|c|c|c|c|c|c|}
\hline \multicolumn{2}{|c|}{ OWAS } & \multicolumn{3}{|c|}{ COSTAS } & \multicolumn{3}{|c|}{ BRAÇOS } & \multicolumn{3}{|c|}{ PERNAS } & \multicolumn{4}{|c|}{ ESFORÇO } & \multicolumn{3}{|c|}{ AÇÃo } & \multicolumn{3}{|c|}{ TEMPO } \\
\hline \multicolumn{21}{|c|}{$\begin{array}{l}\text { A Categoria de Ação é avaliada levando em consideração os digitos dos fatores avaliados. } \\
\text { Existem quatro Categorias de Açẫo conforme mostrado na tabela abaixo: }\end{array}$} \\
\hline \multirow{4}{*}{ Costas } & \multirow{4}{*}{ Braços } & \multicolumn{19}{|c|}{ Pernas } \\
\hline & & \multicolumn{3}{|c|}{1} & \multicolumn{2}{|r|}{2} & \multicolumn{3}{|c|}{3} & \multicolumn{3}{|c|}{4} & \multicolumn{3}{|c|}{5} & \multicolumn{2}{|r|}{6} & \multicolumn{3}{|c|}{7} \\
\hline & & \multicolumn{3}{|c|}{ Força } & \multicolumn{2}{|c|}{ Força } & \multicolumn{3}{|c|}{ Força } & \multicolumn{3}{|c|}{ Força } & \multicolumn{3}{|c|}{ Força } & \multicolumn{2}{|c|}{ Força } & \multicolumn{3}{|c|}{ Força } \\
\hline & & 1 & \begin{tabular}{|l|}
2 \\
\end{tabular} & 3 & 1 & \begin{tabular}{l|l}
2 & 3 \\
\end{tabular} & 1 & 2 & 3 & 1 & 2 & 3 & 1 & \begin{tabular}{l|l}
2 \\
\end{tabular} & 3 & \begin{tabular}{l|l}
1 & 2 \\
\end{tabular} & \begin{tabular}{l|l}
2 & 3 \\
\end{tabular} & 1 & 2 & 3 \\
\hline \multirow{3}{*}{1} & 1 & 1 & 1 & 1 & 1 & 1 & 1 & 1 & 1 & 2 & 2 & 2 & 2 & 2 & 2 & 1 & 1 & 1 & 1 & 1 \\
\hline & 2 & 1 & 1 & 1 & 1 & 1 & 1 & 1 & 1 & 2 & 2 & 2 & 2 & 2 & 2 & 1 & 1 & 1 & 1 & 1 \\
\hline & 3 & 1 & 1 & 1 & 1 & 1 & 1 & 1 & 1 & 2 & 2 & 3 & 2 & 2 & 3 & 1 & 1 & 1 & 1 & 2 \\
\hline \multirow{3}{*}{2} & 1 & 2 & 2 & 3 & 2 & 2 & 2 & 2 & 3 & 3 & 3 & 3 & 3 & 3 & 3 & 2 & 2 & 2 & 3 & 3 \\
\hline & 2 & 2 & 2 & 3 & 2 & 2 & 2 & 3 & 3 & 3 & 4 & 4 & 3 & 4 & 4 & 3 & 3 & 2 & 3 & 4 \\
\hline & 3 & 3 & 3 & 4 & 2 & 2 & 3 & 3 & 3 & 3 & 4 & 4 & 4 & 4 & 4 & 4 & 4 & 2 & 3 & 4 \\
\hline & 1 & 1 & 1 & 1 & 1 & 1 & 1 & 1 & 2 & 3 & 3 & 3 & 4 & 4 & 4 & 1 & 1 & 1 & 1 & 1 \\
\hline 3 & 2 & 2 & 2 & 3 & 1 & 1 & 1 & 1 & 2 & 4 & 4 & 4 & 4 & 4 & 4 & 3 & 3 & 1 & 1 & 1 \\
\hline & 3 & 2 & 2 & 3 & 1 & 1 & 2 & 3 & 3 & 4 & 4 & 4 & 4 & 4 & 4 & 4 & 4 & 1 & 1 & 1 \\
\hline & 1 & 2 & 3 & 3 & 2 & 2 & 2 & 2 & 3 & 4 & 4 & 4 & 4 & 4 & 4 & 4 & 4 & 2 & 3 & 4 \\
\hline 4 & 2 & 3 & 3 & 4 & 2 & 3 & 3 & 3 & 4 & 4 & 4 & 4 & 4 & 4 & 4 & 4 & 4 & 2 & 3 & 4 \\
\hline & 3 & 4 & 4 & 4 & 2 & \begin{tabular}{l|l}
3 & 4 \\
\end{tabular} & 3 & 3 & 4 & 4 & 4 & 4 & 4 & 4 & 4 & 4 & 4 & 2 & 3 & 4 \\
\hline CATEG & ORLAS D & E A & ÇAC & & & & & & & & & & & & & & & & & \\
\hline 1 - Não & são neces & ssáric & as me & edid. & as co & orretivas & & & & & & & & & & & & & & \\
\hline 2 - São & necessária & as co & rreçô & ões & $\mathrm{em} u$ & m futurc & prós & imo & & & & & & & & & & & & \\
\hline 3 - São & necessária & $\mathrm{asco}$ & rreçô & ões t & ão 1 & ogo qua & to $\mathrm{p}$ & ossiv & & & & & & & & & & & & \\
\hline 4 - São & & & & & & iatas & & & & & & & & & & & & & & \\
\hline
\end{tabular}

Fonte: FBF Sistemas (2018).

O método classifica as categorias de ação em 4 níveis conforme os resultados das avaliações das posturas obtidas e as relaciona entre si.

Após análise dos dados, elaborou-se um Mapa de Riscos, apontando o tipo de risco identificado, sua intensidade e o número de colabores expostos em cada setor e, a partir disto, foram propostas soluções para os problemas através de melhorias nos processos e ambiente de trabalho.

\section{DESENVOLVIMENTO}

A empresa trata-se de um Laboratório de Prótese Odontológica, que conta com uma equipe de 6 colaboradores, sendo que, destes, 4 trabalham no processo produtivo e geralmente ultrapassam a carga horária de trabalho de $8 \mathrm{~h}$ diárias pois são comissionados e, desta forma, a jornada varia conforme a demanda.

Os demais colaboradores seguem a jornada regular de trabalho, sendo 1 na entrega de produtos e 1 na administração.

O Laboratório é dividido em 6 setores (Figura 6), sendo eles, setor de gesso, setor de usinagem, sala de enceramento e aplicação de cerâmica, sala de fundição, sala de jateamento, recepção e escritório. 
Figura 6 - Planta Baixa da Empresa

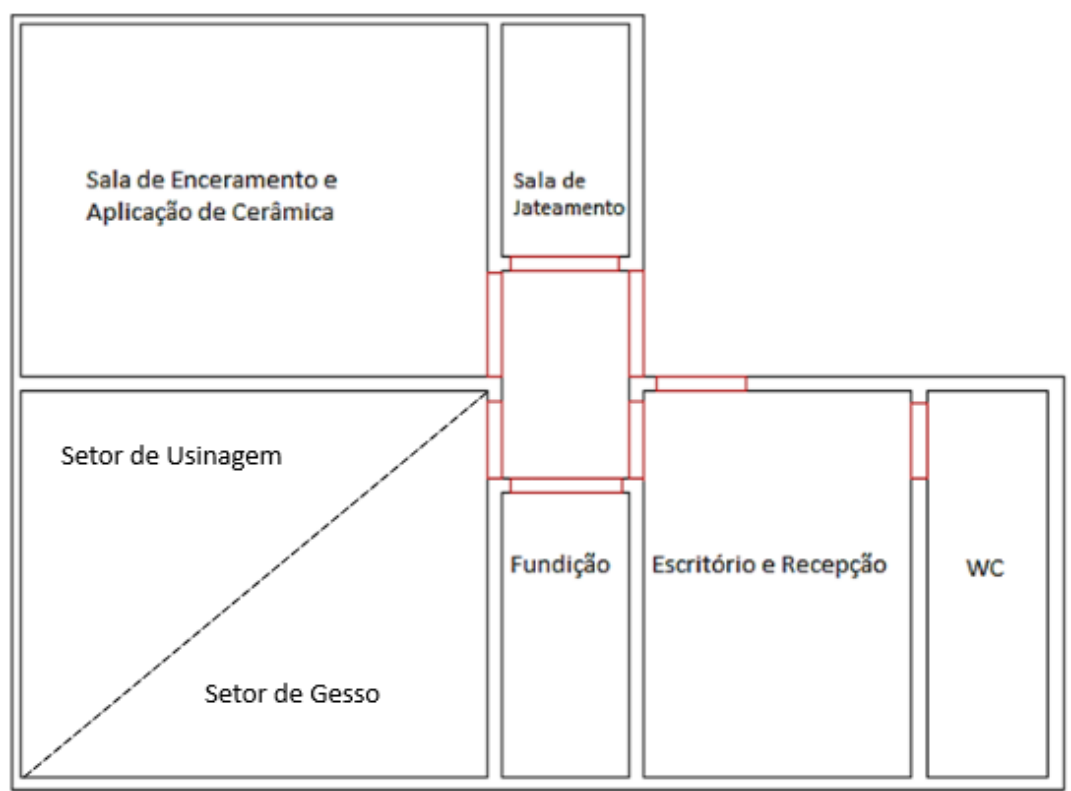

Fonte: Autoria própria (2019)

Na sala de gesso e usinagem, separadas por uma linha imaginária, consta uma pia, um espatulador à vácuo, um cortador de gesso com fluxo de água, uma politriz para polimento das peças, um recortador de palato e duas bancadas de trabalho com gaveta.

Em cada bancada há um motor elétrico de bancada, sendo um para preparação dos moldes de gesso e outro para usinagem das peças metálicas (Figura 7).

Figura 7 - Setor de Envase de Gesso

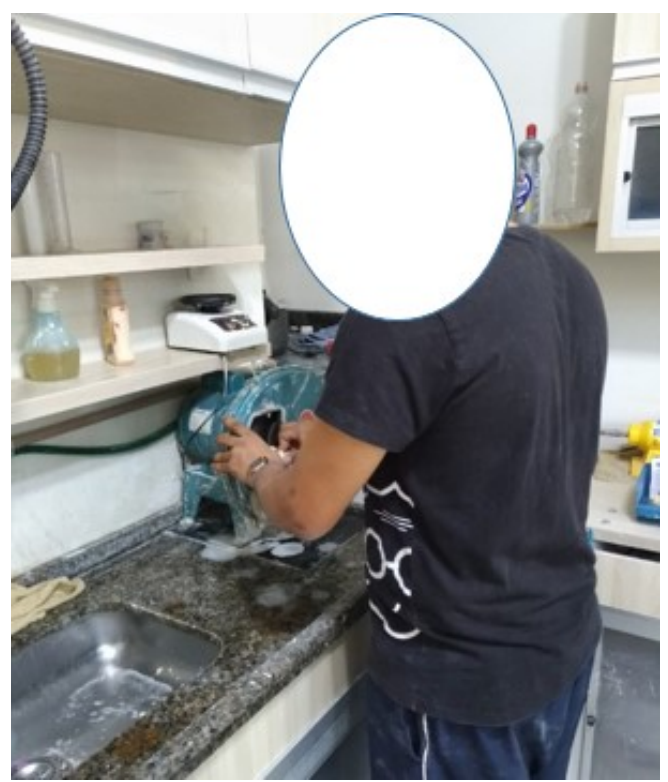

Fonte: Autoria própria (2019)

Conforme apresentado na Figura 7, o trabalhador durante sua jornada de trabalho executa as atividades de envase das moldagens e recorte dos modelos 
de gesso de pé, e os modelos e equipamentos permanecem sobre a pia. Somente o acabamento final dos modelos é feito na bancada, onde o colaborador permanece sentado.

$\mathrm{Na}$ sala de enceramento e aplicação de cerâmica (Figura 8) existem 3 bancadas de trabalho, sendo duas para enceramento, onde, cada uma possui um gotejador elétrico para realizar o enceramento das peças. A outra bancada contém um forno para queima da cerâmica o qual funciona com uma bomba de vácuo.

Figura 8: Sala de enceramento e aplicação de cerâmica

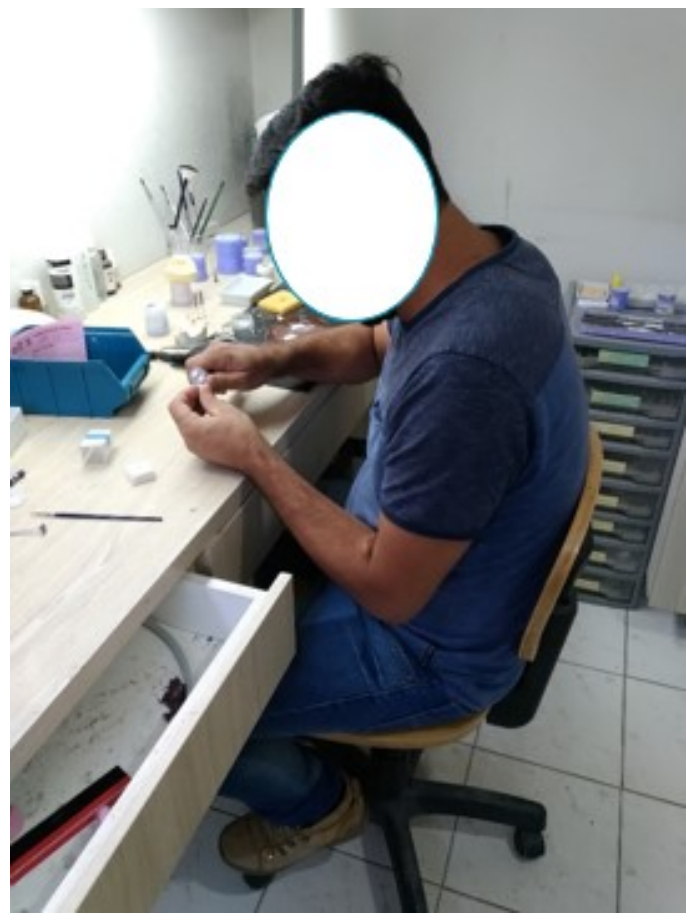

Fonte: Autoria própria (2019)

A partir da Figura 8, é possível observar que o colaborador realiza as atividades de aplicação de cerâmica e acabamento sobre a bancada, onde permanece o dia todo sentado e com as costas inclinadas. Além disso, conforme a demanda de trabalho, o colaborador pode permanecer sentado por longos períodos, sem levantar ou realizar pausas, apenas movimentações curtas com auxílio da cadeira, que possui rodas.

A sala de Fundição (Figura 9), possui dois Fornos para Anéis para eliminação da cera, uma pia, um fogão industrial, uma centrífuga de molas, há também um cilindro de oxigênio e um botijão de gás que são utilizados na fundição do metal. Já na sala de jateamento.

Há dois jateadores com exaustor de pó para realizar o jateamento das peças de metal e cerâmica, o pó é enviado para sacos e posteriormente será peneirado e reutilizado. Por último, a sala de recepção que contém mesa e computador. 
Figura 9 - Forno de Eliminação de Cera

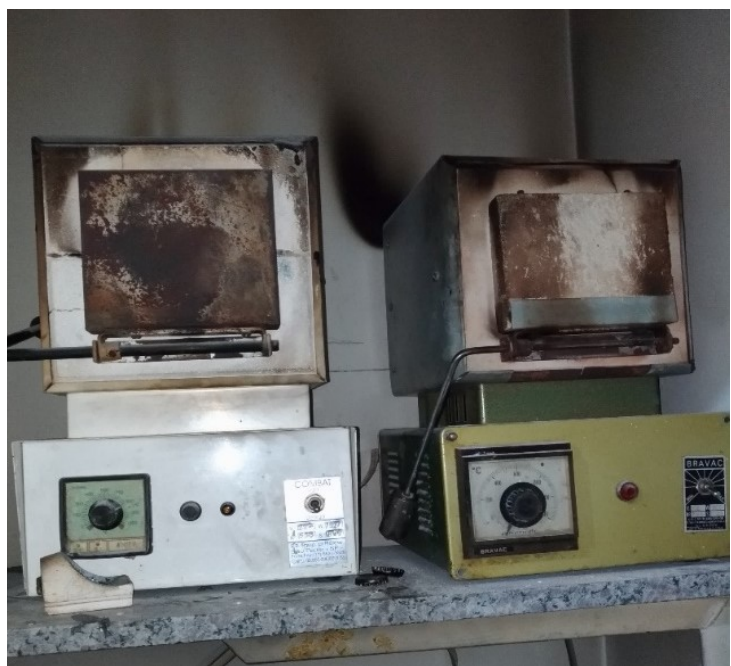

Fonte: Autoria própria (2019)

Conforme observado na Figura 9, os fornos de eliminação de cera não estão em um bom estado de conservação, sendo que algumas partes estão avariadas e, a vedação das portas está comprometida, e com isto, a fumaça exaurida da queima tem sua saída pela frente do forno.

Figura 10: Centrífuga de Molas

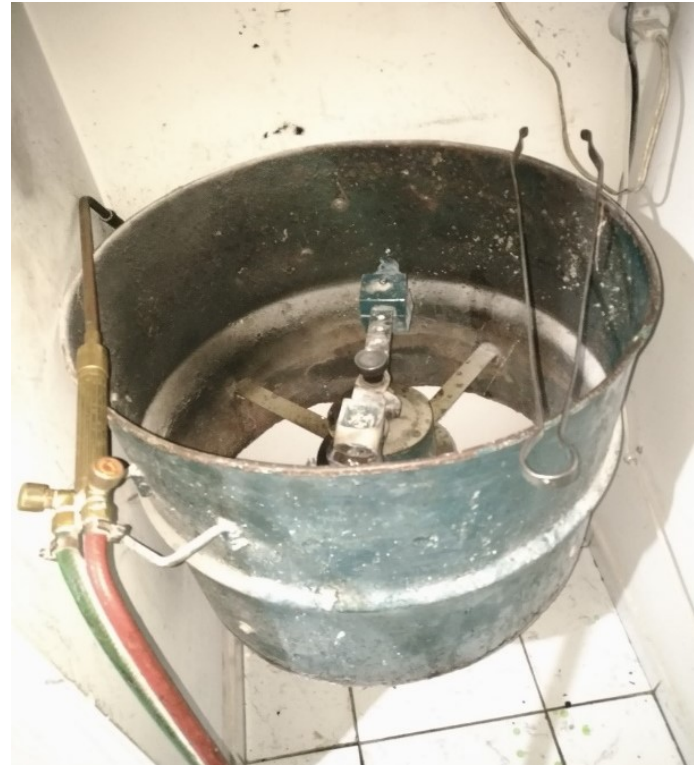

Fonte: Autoria própria (2019)

A Figura 10 apresenta a centrífuga de molas que é utilizada na fundição do metal nos anéis de revestimento, os quais são colocados em um suporte a em frente a um cadim de revestimento onde, é inserido o metal para ser fundido com o maçarico. Pode-se observar também, que não há uma proteção adequada que impeça a propagação de metal fundido, e além disso, o equipamento não está em bom estado de conservação.

O laboratório fabrica próteses odontológicas que são divididas em quatro tipos, metalo-cerâmica que é a prótese feita de metal (níquel cromo) e porcelana 
que pode ser coroa fixa ou sob implante. Coroas fixas E-MAX (metal free), é um tipo de prótese que utiliza o material feito de óxido de zircônio no lugar do metal, o que traz melhor qualidade estética ao produto. Além destes produtos, também são feitas facetas cerâmicas e lentes de contato, que são tipos de próteses que são utilizadas sobre os dentes, apenas para correção da estética. Em média, por mês, o laboratório produz 100 próteses em metalocerâmica, tanto fixas como sob implantes, 60 próteses E-MAX e 60 próteses, divididas entre facetas e lentes de contato.

Em geral, o processo se inicia na sala de gesso onde os trabalhos enviados pelas clínicas odontológicas são recebidos para que as moldagens dos pacientes sejam envasadas com gesso. Após serem envasadas, os moldes serão enviados para o enceramento das coroas metálicas, no caso das metalo-cerâmicas, e enceramento dos dentes, no caso dos outros produtos, que varia conforme o tipo de trabalho solicitado pelo cliente.

Facetas e lentes de contado serão enceradas, enviadas ao cliente para prova, e posteriormente retornam para aplicação de cerâmica. No caso das metalocerâmicas, as coroas enceradas serão envasadas com revestimento em anéis de silicone que, após secarem são desenformados e enviados à sala de fundição.

Nesta etapa, as peças permanecem no forno à $900{ }^{\circ} \mathrm{C}$ por 30 minutos, para derretimento e queima de toda a cera e, em seguida, após resfriamento, o anel de revestimento é colocado em uma centrífuga de mola, para introdução do metal. Para introdução do metal na peça, o mesmo deve colocado na centrífuga em um cadim de cerâmica, e deverá ser derretido através de um maçarico até que esteja no estado líquido, com isto, aciona-se a centrífuga manualmente e o metal já derretido é inserido na peça contida dentro do revestimento.

O processo produtivo (Figura 11) se baseia no método de produção puxada, ou seja, os produtos só serão fabricados após requisição dos clientes pois cada trabalho executado é específico e varia de cliente para cliente. Após a fundição, as peças vão para a sala de jateamento, onde receberão jatos de microesfera de vidro para que sejam retirados as sujeiras e resíduos de revestimento interno e externamente. Feito isso, as peças voltam para a sala de usinagem para receberem o acabamento e ao fim deste processo elas serão enviadas aos clientes para serem provadas diretamente nos pacientes.

Caso a peça não encaixe ela retornará ao laboratório, para que seja feito ajuste ou em casos extremos, a confecção de uma nova peça. Depois de provada a peça, ela volta ao laboratório, para a sala de aplicação de cerâmica, onde serão esculpidas as próteses. No processo de aplicação de cerâmica, a prótese é enviada para um forno de uso exclusivo para queima da cerâmica, e em seguida receberá acabamento e será enviada ao cliente para uma última prova. Após a prova da prótese ela retorna ao laboratório para receber o acabamento final e por fim é destinada ao cliente. 
Figura 11 - Fluxograma do processo

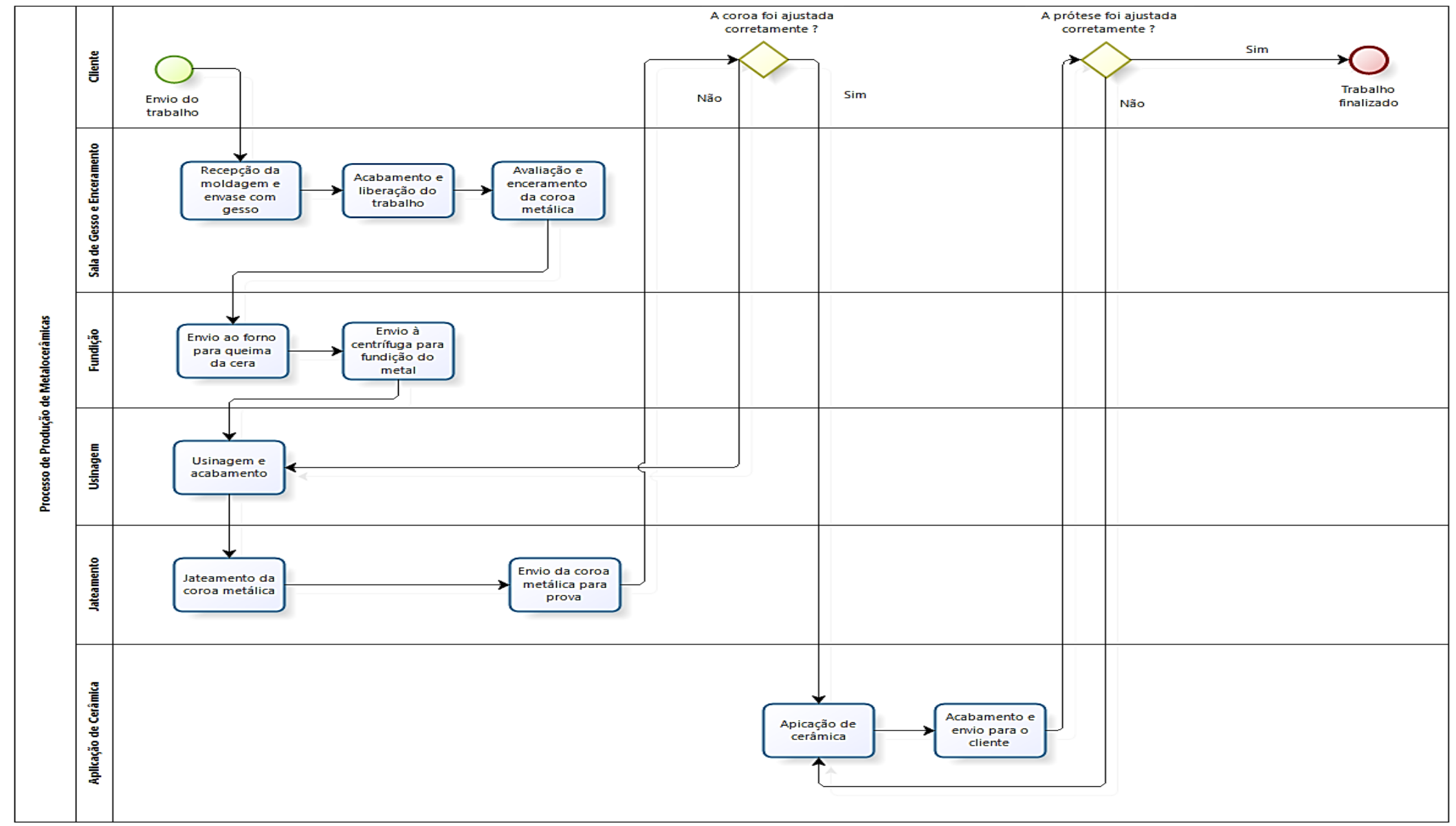

Fonte: Autoria própria (2019) 


\section{ANÁLISE ERGONÔMICA}

Análise das posturas de trabalho dos colaboradores foi efetuada com base nos dados obtidos dos questionários preenchidos pelos colaboradores juntamente com a avaliação visual efetuada no ambiente de trabalho durante a visita à empresa. $O$ diagnóstico destes dados foi realizado utilizando-se o método OWAS, com auxílio do software Ergolândia (Figura 12).

Figura 12: Interface do Software Ergolândia para o Método OWAS

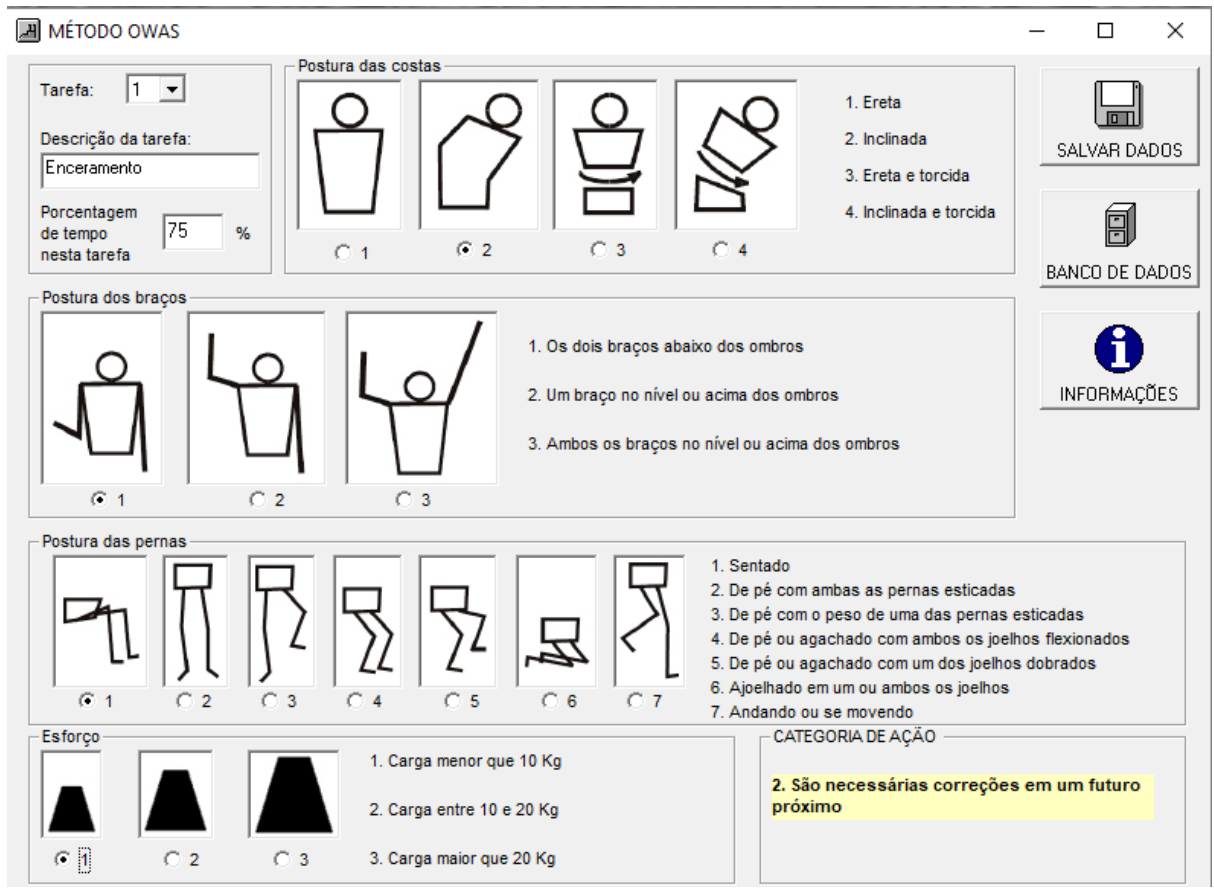

Fonte: FBF Sistemas (2018).

Através disto, foi possível realizar a análise de cada tarefa que os colaboradores executam durante sua jornada de trabalho, além de se obter o nível de ação que deverá ser tomada conforme cada atividade.

Para o setor de gesso, a postura de trabalho é na maior parte do tempo em pé e com a costas inclinadas, onde passa cerca de $75 \%$ do tempo vazando as moldagens e dando acabamento na pia e no balcão do recortador de gesso. 0 restante do tempo ele passa sentado realizando os acabamentos finais para que possa repassar o modelo de trabalho para os demais setores, e em ambos os casos, a carga de trabalho é inferior a $10 \mathrm{Kg}$.

No setor de usinagem, o colaborador passa cerca de $93 \%$ do tempo sentado e com as costas inclinadas sobre a bancada, onde efetua o enceramento e usinagem das peças de trabalho. No restante do tempo é realizada as atividades no setor de fundição, onde o colaborador permanece em pé e com as costas eretas e em todas estas atividades a carga de trabalho é inferior a $10 \mathrm{Kg}$.

Os dois colaboradores que atuam no setor de aplicação de cerâmica executam suas tarefas $100 \%$ do tempo sentados e com as costas inclinadas sobre a bancada de trabalho onde fazem o enceramento e aplicação de cerâmica. Nos dois casos a carga de trabalho executada é inferior a $10 \mathrm{Kg}$. 
Por último, o setor administrativo no qual a colaboradora permanece metade do tempo em pé e o restante sentada, sempre com as costas eretas e em suas atividades não movimenta nenhum tipo de carga. Com a utilização do software, os resultados obtidos (Quadro 1) na utilização do método OWAS revelaram quais atividades necessitam serem revisadas e melhor pensadas para que possam reduzir ou eliminar problemas futuros aos colaboradores.

O mapa de riscos nada mais é do que a representação gráfica baseada no layout da instituição, com os riscos presentes no local. Os riscos já citados anteriormente, são divididos por cores, onde cada cor representa um tipo de risco, e cada cor será subdividida em círculos no qual o diâmetro varia conforme a gravidade do risco que representa (PORTO, 2008).

Quadro 1 - Resultado das análises obtidas pelo método OWAS

\begin{tabular}{|c|c|c|c|c|c|}
\hline Atividade & Costas & Braços & Pernas & Esforço & $\begin{array}{c}\text { Categoria } \\
\text { da Ação }\end{array}$ \\
\hline Setor de Gesso & Inclinadas & Abaixo dos ombros & De pé & $>10 \mathrm{Kg}$ & 2 \\
\hline $\begin{array}{c}\text { Aplicação de } \\
\text { Cerâmica }\end{array}$ & Inclinadas & Abaixo dos ombros & Sentado & $>10 \mathrm{Kg}$ & 2 \\
\hline Usinagem & Inclinadas & Abaixo dos ombros & Sentado & $>10 \mathrm{Kg}$ & 2 \\
\hline Enceramento & Inclinadas & Abaixo dos ombros & Sentado & $>10 \mathrm{Kg}$ & 2 \\
\hline Administrativo & Ereta & Abaixo dos ombros & Sentado & $>10 \mathrm{Kg}$ & 1 \\
\hline
\end{tabular}

Fonte: Autoria própria (2019)

Conforme observa-se no Quadro 1 em relação as costas, apenas no setor administrativo o colaborador trabalha com a postura ereta, no restante todos trabalham com as costas inclinadas, e em todos os setores as atividades são executadas com os braços abaixo dos ombros. Sobre o esforço nas pernas, apenas o colaborador do setor de gesso passa o dia em pé, o restante passa o dia sentados e, todas as tarefas realizadas no setor produtivo exigem um esforço baixo com uma carga menos que 10 quilogramas.

Relacionando estes resultados, é possível identificar a categoria de ação que deve ser tomada e, neste caso, foi igual a 2 para todos setores do processo produtivo. Tal resultado significa que, deverão ser realizadas correções em um futuro próximo, já no setor administrativo, a classificação obtida foi categoria 1 no qual a metodologia avalia que não serão necessárias medidas corretivas.

\section{ANÁLISE PRELIMINAR DE RISCOS}

A análise dos riscos foi efetuada através de visitas à empresa onde foram aplicados questionários de percepção aos colaboradores durante o expediente, além disso, foi feita uma análise visual da execução das atividades durante o itinerário de trabalho. Com isso, foi possível efetuar a análise preliminar de riscos e identificar os riscos presentes nas atividades.

Dos 4 colaboradores que atuam no processo produtivo, 3 deles passam a maior parte do tempo sentados, os quais atuam no enceramento, usinagem e aplicação de cerâmica e ambos disseram ter um nível baixo de cansaço, porém sentem maior desconforto e dores nas costas ao final do dia. Já o colaborador que atua no setor de gesso passa a maior parte da sua rotina diária de trabalho 
em pé, seu nível de cansaço é médio e seu maior desconforto é nas pernas e costas onde sente dores ao final do dia.

A colaboradora responsável pela parte administrativa exerce sua função sentada durante todo o dia, tem um nível de cansaço baixo e apresenta um desconforto nas costas ao final do dia. Por último, o colaborador responsável pelas entregas, as quais executa de motocicleta, passa maior parte do tempo na rua, buscando e entregando os trabalhos e seu nível de cansaço é baixo e a atividade não lhe proporciona desconforto.

Com base nas respostas obtidas nos questionários e pela análise efetuada no ambiente de trabalho foi possível identificar os riscos aos quais os colaboradores estão expostos em cada setor do processo produtivo. A avaliação dos riscos foi feita conforme probabilidade de ocorrência e gravidade, (Quadros 2 a 5) utilizando-se a matriz de classificação de riscos (Figura 1) para relacioná-las e qualificar o nível de cada riscos.

De acordo com o questionário de percepção, o colaborador que atua no setor de gesso (Quadro 2), respondeu que passa aproximadamente seis horas de pé envazando moldagens e o restante do tempo permanece sentado para efetuar o acabamento dos moldes. Seu nível de cansaço é maior quando trabalha de pé e ao final do dia sua maior queixa são dores nas costas e pernas.

Quadro 2: Análise Preliminar de Riscos do setor de Gesso

\begin{tabular}{|l|l|l|l|l|l|l|}
\hline \multicolumn{3}{|c|}{ Identificação dos Riscos } & \multicolumn{3}{c|}{ Avaliação dos Riscos } \\
\hline Risco & Causa & Efeito & Ocorrência & Gravidade & $\begin{array}{l}\text { Grau } \\
\text { de } \\
\text { Risco }\end{array}$ & $\begin{array}{l}\text { Possíveis } \\
\text { medidas }\end{array}$ \\
\hline Acidente & $\begin{array}{l}\text { Recortador } \\
\text { de gesso }\end{array}$ & Pequenas lesões & Média & Baixa & 2 & $\begin{array}{l}\text { Uso de EPI }- \\
\text { Equipamento } \\
\text { de Proteção } \\
\text { Individual }\end{array}$ \\
\hline Biológico & $\begin{array}{l}\text { Moldagem } \\
\text { da boca do } \\
\text { paciente }\end{array}$ & Contaminação & Baixa & Média & 2 & $\begin{array}{l}\text { Esterilização } \\
\text { das } \\
\text { moldagens }\end{array}$ \\
\hline Ergonômico & $\begin{array}{l}\text { Postura de } \\
\text { trabalho } \\
\text { inadequada }\end{array}$ & $\begin{array}{l}\text { Dores nas costas e } \\
\text { pernas }\end{array}$ & Média & Média & 4 & $\begin{array}{l}\text { Adaptação do } \\
\text { ambiente de } \\
\text { trabalho }\end{array}$ \\
\hline
\end{tabular}

Fonte: Autoria própria (2019)

Conforme o Quadro 2, os riscos identificados foram, risco de acidente no cortador de gesso, sendo sua ocorrência média (2), e caso ocorra a gravidade seria baixa (1). Risco ergonômico, sendo sua ocorrência média (2) e gravidade média (2). Outro risco encontrado foi o risco biológico causado pelo contato com a moldagem da boca do paciente, sendo a ocorrência baixa (1), e sua gravidade é média (2).

Já o colaborador que atua no setor de usinagem (Quadro 3) relatou uma carga de trabalho de aproximadamente sete horas sentado, das quais são intercaladas entre o enceramento das peças e, após a fundição, a usinagem das peças, todos na bancada de trabalho. O restante do tempo ele realiza as atividades no setor de fundição (Quadro 4) onde permanece pouco tempo de pé e, seu cansaço ao longo do dia é baixo e sua única reclamação foi em relação a dores nas costas ao final do dia. 
Quadro 3: Análise Preliminar de Riscos do setor de Usinagem

\begin{tabular}{|c|c|c|c|c|c|c|}
\hline \multicolumn{3}{|c|}{ Identificação dos Riscos } & \multicolumn{4}{|c|}{ Avaliação dos Riscos } \\
\hline Risco & Causa & Efeito & $\begin{array}{c}\text { Ocorrên- } \\
\text { cia }\end{array}$ & $\begin{array}{l}\text { Gravi- } \\
\text { dade }\end{array}$ & $\begin{array}{c}\text { Grau de } \\
\text { Risco }\end{array}$ & $\begin{array}{l}\text { Possíveis } \\
\text { medidas }\end{array}$ \\
\hline Acidente & $\begin{array}{l}\text { Manuseio } \\
\text { inadequado } \\
\text { dos } \\
\text { equipamentos }\end{array}$ & $\begin{array}{l}\text { Pequenas } \\
\text { lesões }\end{array}$ & Média & Baixa & 2 & $\begin{array}{l}\text { EPI - } \\
\text { Equipamento } \\
\text { de Proteção } \\
\text { Individual }\end{array}$ \\
\hline Químico & $\begin{array}{l}\text { Pó resultante } \\
\text { da usinagem } \\
\text { do metal }\end{array}$ & $\begin{array}{l}\text { Doenças } \\
\text { respiratórias }\end{array}$ & Média & Baixa & 2 & $\begin{array}{l}\text { EPI - } \\
\text { Equipamento } \\
\text { de Proteção } \\
\text { Individual }\end{array}$ \\
\hline Ergonômico & $\begin{array}{l}\text { Postura de } \\
\text { trabalho } \\
\text { inadequada }\end{array}$ & $\begin{array}{l}\text { Dores nas } \\
\text { costas e } \\
\text { doenças } \\
\text { ocupacionais }\end{array}$ & Média & Média & 4 & $\begin{array}{l}\text { Adaptação da } \\
\text { postura de } \\
\text { trabalho }\end{array}$ \\
\hline
\end{tabular}

Fonte: Autoria própria (2019)

De acordo com o Quadro 3, os riscos identificados foram, risco de acidente no manuseio dos equipamentos, sendo sua ocorrência média (2), e sua gravidade é baixa (1). Também foi avaliado a existência de risco químico devido a poeira residual do metal usinado, sua ocorrência é média (2), e sua gravidade é baixa (1), e por último avaliou-se o risco ergonômico devido ao trabalho sentado na mesma posição durante todo o dia, tendo uma ocorrência alta (3), sua gravidade é média (2), podendo causar doenças ocupacionais.

Quadro 4: Análise Preliminar de Riscos do setor de Fundição

\begin{tabular}{|c|c|c|c|c|c|c|}
\hline \multicolumn{3}{|c|}{ Identificação dos Riscos } & \multicolumn{4}{|c|}{ Avaliação dos Riscos } \\
\hline Risco & Causa & Efeito & Ocorrência & Gravidade & $\begin{array}{c}\text { Grau } \\
\text { de } \\
\text { Risco }\end{array}$ & $\begin{array}{l}\text { Possíveis } \\
\text { medidas }\end{array}$ \\
\hline Químico & $\begin{array}{c}\text { Fumaça } \\
\text { emitida pelo } \\
\text { forno de } \\
\text { eliminação de } \\
\text { cera. }\end{array}$ & Intoxicação. & Baixa. & Baixa. & 1 & $\begin{array}{c}\text { EPI - } \\
\text { Equipamento } \\
\text { de Proteção } \\
\text { Individual. }\end{array}$ \\
\hline Acidente & $\begin{array}{l}\text { Manuseio do } \\
\text { metal fundido } \\
\text { durante a } \\
\text { centrifugação. }\end{array}$ & Queimaduras. & Baixa & Média & 2 & EPI e EPC. \\
\hline
\end{tabular}

Fonte: Autoria própria (2019)

Já na análise realizada no setor de fundição (Quadro 4) identificou-se o risco químico resultante da fumaça do forno onde é queimada a cera, tendo uma ocorrência baixa (1) e gravidade também é baixa (1). Identificou-se também o risco de acidente decorrente do manuseio do metal fundido na centrífuga, sendo que sua ocorrência é média (2), e a sua gravidade também é média (2) podendo causar pequenas queimaduras.

Em relação aos colaboradores que executam suas atividades no setor de aplicação de cerâmica (Quadro 5), ambos permanecem o dia todo sentados e, apesar de afirmarem ter um nível de cansaço baixo, os dois sentem dores nas costas ao final do dia. Isto está diretamente relacionado as posturas inadequadas de trabalho.

Quadro 5: Análise Preliminar de Riscos do setor de Aplicação de Cerâmica. 


\begin{tabular}{|c|c|c|c|c|c|c|}
\hline \multicolumn{2}{|c|}{ Identificação dos Riscos } & \multicolumn{3}{c|}{ Avaliação dos Riscos } \\
\hline Risco & Causa & Efeito & Ocorrência & Gravidade & $\begin{array}{c}\text { Grau } \\
\text { de } \\
\text { Risco }\end{array}$ & $\begin{array}{c}\text { Possíveis } \\
\text { medidas }\end{array}$ \\
\hline Químico & $\begin{array}{c}\text { Pó } \\
\text { resultante } \\
\text { do } \\
\text { acabamento } \\
\text { do produto }\end{array}$ & $\begin{array}{c}\text { Doenças } \\
\text { respiratórias }\end{array}$ & Baixa & Baixa & 1 & $\begin{array}{c}\text { Equipamento } \\
\text { de Proteção } \\
\text { Individual }\end{array}$ \\
\hline $\begin{array}{c}\text { Postura de } \\
\text { trabalho } \\
\text { inadequada }\end{array}$ & $\begin{array}{c}\text { Dores nas } \\
\text { costas e } \\
\text { doenças } \\
\text { ocupacionais }\end{array}$ & Média & Média & 4 & $\begin{array}{c}\text { Adaptação da } \\
\text { postura de } \\
\text { trabalho }\end{array}$ \\
\hline
\end{tabular}

Fonte: Autoria própria (2019)

Conforme Quadro 5, os riscos identificados foram os mesmos, risco químico resultante da poeira exalada durante a realização do acabamento das peças, sendo sua ocorrência baixa (1), e sua gravidade baixa (1). Há também o risco ergonômico em consequência do trabalho sentado durante longo período do dia, tendo uma ocorrência alta (3), e a gravidade de nível médio (2).

Ainda em relação as análises efetuadas na empresa, pode-se observar quais os Equipamentos de proteção individual (EPI) são fornecidos aos colaboradores do processo produtivo, de acordo com as atividades de cada setor. São estes, máscaras de proteção e óculos de proteção que são de dois tipos, incolores e escuros. As máscaras de proteção são utilizadas para impedir que as poeiras resultantes dos processos, sejam inaladas pelos colaboradores. Elas são utilizadas nos setores de gesso, usinagem e aplicação de cerâmica, principalmente na execução do processo de acabamento das peças.

Os óculos de proteção também são utilizados na parte de acabamento das peças, nos setores de gesso, usinagem e aplicação de cerâmica e sua função é impedir que resíduos e fragmentos resultantes das peças e dos equipamentos atinjam o olho dos colaboradores. Já os óculos escuros são utilizados no setor de fundição e sua função é proteger o colaborador da luminosidade intensa resultante da fundição do metal e que pode causar danos oculares ao colaborador.

\section{MAPA DE RISCOS}

A partir da identificação e análise dos riscos das atividades em cada setor, tornou-se possível a elaboração do mapa de riscos (Figura 13) sobre a planta baixa da empresa. As análises levaram em conta o ambiente de trabalho, o processo produtivo, os riscos identificados, o grau de risco avaliado em cada setor, o grau de risco avaliado em cada atividade e o nível de exposição ao risco de cada colaborador.

Figura 13: Mapa de Riscos sobre a planta baixa da empresa 


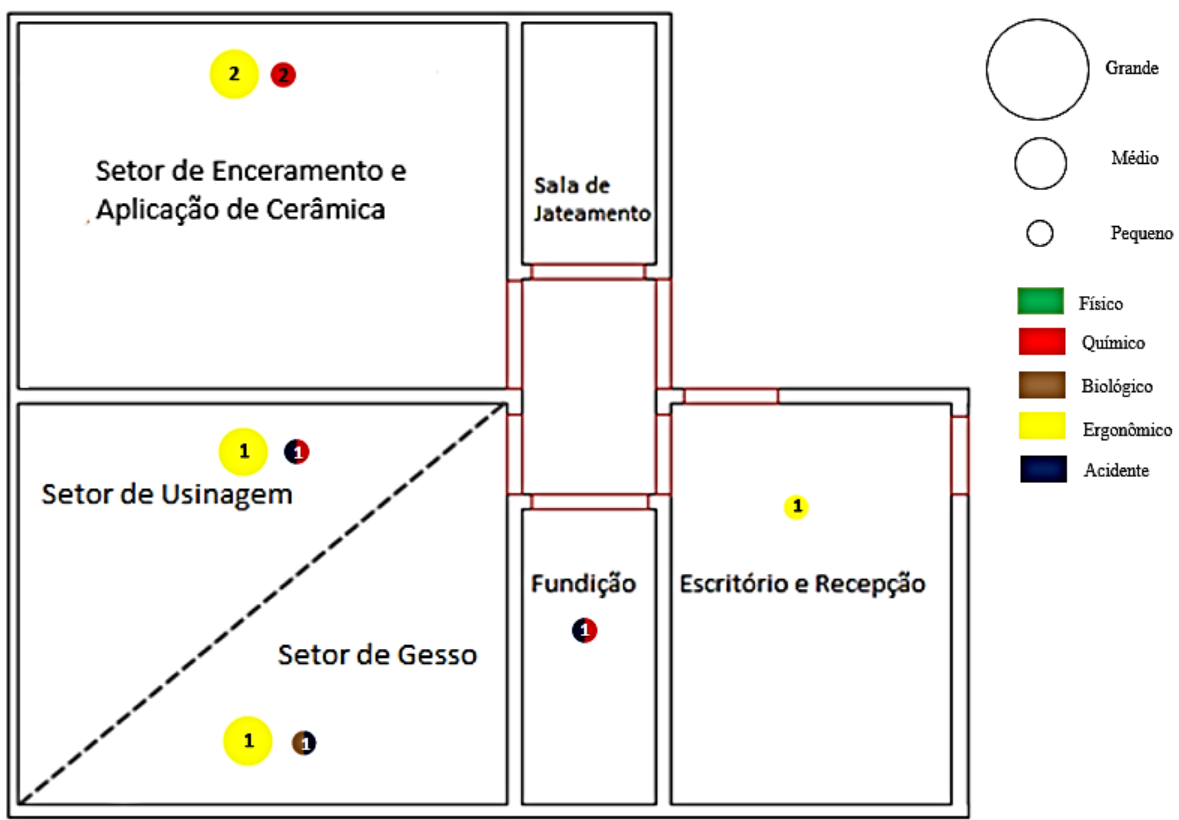

Fonte: Autoria própria (2019)

Como pode ser visto no mapa de riscos, a maioria dos riscos avaliados tem um nível de intensidade baixa sendo que, apenas o risco ergonômico possui intensidade média, devido em parte pela falta de conscientização dos colaboradores sobre como manter uma postura correta ao executar as atividades, e sobre os riscos acometidos a isto.

Além disso, os colaboradores deveriam efetuar pausas durante as atividades, pois os mesmos passam a maior parte do dia sentados, sentam-se de maneira incorreta e não ajustam as cadeiras para que fiquem à mesma altura que a bancada de trabalho. No setor de gesso há a necessidade de corrigir o ambiente de trabalho, principalmente a altura dos equipamentos, para que o colaborador não fique com a coluna curvada durante a execução das atividades.

Sobre os riscos químicos e de acidentes, observou-se que a correta utilização de EPIs reduz em grande parte a ocorrência do risco, falta também neste caso é a conscientização dos funcionários para que utilizem os EPIs fornecidos e sobre as consequências do não uso.

Em relação ao risco biológico, há a conscientização sobre a realização dos procedimentos corretos que evitem tal risco mas deve-se reforçar também o uso de EPIs para mitigar tal risco.

A análise dos riscos foi efetuada através de visitas à empresa onde foram aplicados questionários de percepção aos colaboradores durante o expediente, além disso, foi feita uma análise visual da execução das atividades durante o itinerário de trabalho. Com isso, foi possível efetuar a análise preliminar de riscos e identificar os riscos presentes nas atividades.

\section{SUGESTÕES DE MELHORIA}

Após avaliados os riscos e elaborado o mapa de riscos, foi possível visualizar quais medidas deveriam ser tomadas para reduzir ou eliminar os riscos presentes em cada setor, com base na APR e apresentá-las ao responsável pela empresa. 
Tais medidas levaram em conta não somente as atividades exercidas, mas também o ambiente de trabalho.

Quadro 6: Medidas Sugeridas por Setor

\begin{tabular}{|c|c|c|}
\hline Setor & $\begin{array}{c}\text { Riscos } \\
\text { Identificados }\end{array}$ & Medida Sugerida \\
\hline \multirow[b]{2}{*}{$\begin{array}{l}\text { Enceramento } \\
\text { e Aplicação de } \\
\text { Cerâmica }\end{array}$} & Químico & Utilização de máscaras de proteção. \\
\hline & Ergonômico & $\begin{array}{c}\text { Correção da altura das cadeiras em relação as } \\
\text { bancadas de trabalho e realização de pausas } \\
\text { durante a execução das atividades. }\end{array}$ \\
\hline \multirow{2}{*}{ Fundição } & Químico & $\begin{array}{l}\text { Utilização de máscaras de proteção e realização de } \\
\text { manutenção ou até mesmo troca dos fornos de } \\
\text { eliminação de cera. }\end{array}$ \\
\hline & Acidente & $\begin{array}{c}\text { Utilização de óculos de proteção, avental e luvas, } \\
\text { correção e ajuste das barreiras de proteção da } \\
\text { centrífuga. }\end{array}$ \\
\hline \multirow[b]{3}{*}{ Gesso } & Biológico & $\begin{array}{l}\text { Utilização de agentes esterilizantes, utilização de } \\
\text { luvas e máscaras de proteção. }\end{array}$ \\
\hline & Acidente & Utilização de óculos de proteção e luvas. \\
\hline & Ergonômico & $\begin{array}{l}\text { Adaptação do ambiente de trabalho em relação à } \\
\text { altura dos equipamentos que estão muito baixos e, } \\
\text { realização de pausas durante a execução das } \\
\text { atividades. }\end{array}$ \\
\hline \multirow{3}{*}{ Usinagem } & Químico & Utilização de máscaras de proteção. \\
\hline & Acidente & $\begin{array}{l}\text { Utilização óculos de proteção, utilização de pinça } \\
\text { no manuseio das peças. }\end{array}$ \\
\hline & Ergonômico & $\begin{array}{c}\text { Correção da altura das cadeiras em relação as } \\
\text { bancadas, pausas durante a execução das } \\
\text { atividades }\end{array}$ \\
\hline Administrativo & Ergonômico & $\begin{array}{l}\text { Executar pausas durante atividades que tenham } \\
\text { longa duração. }\end{array}$ \\
\hline
\end{tabular}

Fonte: Autoria própria (2019)

No setor de gesso, em relação ao risco de acidente, o uso de EPI, no caso luvas e óculos de proteção, já serão suficientes para reduzir o risco ao colaborador, além da conscientização ao mesmo para que os use. Em relação ao risco biológico resultante da manipulação das moldagens da boca dos pacientes, a medida a ser tomada foi a correta higienização das mesmas pelo uso de antissépticos que não interfiram nas propriedades do material, sendo o mais usual o Álcool $70^{\circ}$, além disso, indica-se o uso de luvas de látex e máscaras descartáveis para maior segurança do colaborador. Sobre os riscos ergonômicos, deve ser feita a correção da altura da pia, e equipamentos de trabalho para que o colaborador não fique com a coluna curvada e, além disso, realizar pausa durante a realização das atividades de trabalho.

Em relação ao setor de usinagem, as medidas sugeridas para reduzir o risco de acidente foi o uso de equipamentos, como pinças, para o manuseio das peças de trabalho, para que assim o colaborador evite utilizar as mãos, e com isso elimine o risco de se lesionar e a utilização de óculos de proteção, caso algum resíduo ou fagulha, resultante da manipulação das peças, atinja os olhos do colaborador. Sobre o risco químico causado pelo pó derivado da usinagem do 
metal, o procedimento mais adequado é a utilização de máscaras que evitem a inalação deste resíduo e protejam o colaborador.

Para o setor de Aplicação de Cerâmica, a proposta elaborada foi para se reduzir o risco químico inerente do processo de realização de acabamento das peças, no qual, deve ser feita a utilização de máscaras de proteção que evitem a inalação dos resíduos. Também foi proposto o ajuste da altura das cadeiras e realização de pausas durante a execução das atividades para reduzir os riscos ergonômicos inerentes do processo.

No setor de fundição, para redução do risco químico emitido pela fumaça gerada no forno, a medida sugerida é a utilização de máscaras de proteção e também a utilização de exaustores para que esta fumaça não se propague pelo laboratório, além da manutenção ou troca dos fornos, já que os mesmo não proporcionam vedação adequada. No caso do risco de acidente causado pela centrifugação do metal fundido, o correto é a utilização EPIs, tais como luvas e jalecos que forneçam a proteção adequada ao colaborador, além de proteções no próprio equipamento (EPC), por meio de barreiras que impeçam a propagação do metal, caso o mesmo venha a ser expelido para fora da centrífuga.

No setor administrativo, a colaboradora sempre intercala sua postura de trabalho, estando em determinado tempo sentada, e em outro momento de pé, o que reduz o risco de obter alguma doença ocupacional relacionada a sua atividade. Contudo, o risco ainda existe, e portanto, é aconselhável que a mesma realize pausas durante a execução de suas atividades Além disso, deve-se instruir tanto a empresa como colaboradores, sobre a importância de se reduzir os riscos presentes no ambiente de trabalho e na realização das atividades de trabalho, para que, sejam eliminadas as chances de contraírem doenças ocupacionais futuramente.

\section{CONSIDERAÇÕES FINAIS}

Este trabalho teve por objetivo avaliar os riscos ocupacionais, aos quais os colaboradores de um laboratório de produtos odontológicos estão expostos. A análise e identificação dos riscos é importante tanto para saúde e segurança do trabalhador, quanto para o desenvolvimento e crescimento da empresa.

Utilizando-se da Análise Preliminar de Riscos, foram identificados os riscos ocupacionais presentes em cada setor da empresa, os quais foram analisados e classificados conforme a gravidade à que expõem o colaborador. Para isso utilizou-se de metodologias de avaliação do grau de risco, como no caso do risco ergonômico onde foi utilizado o método OWAS para avaliação dos riscos.

Em relação aos riscos identificados, não foram avaliados riscos de grau alto dos quais devessem ser tratados com urgência, porém, é importante tratar tais riscos para que não tragam nenhum malefício ao colaborar, principalmente no caso do risco ergonômico. Tal risco foi considerado de grau médio na maioria dos setores, devido ao longo período sentado durante a execução das atividades e também, sobre a falta de conscientização sobre manter uma postura adequada e realizar pausa durante o período de trabalho.

Com a elaboração do mapa de riscos, tornou-se muito mais fácil a visualização dos riscos que antes, não eram notados ou eram desconhecidos. $E$ 
com isto, é possível mostrar aos envolvidos como é importante avaliar e prevenir tais riscos. Para o desenvolvimento do presente trabalho as dificuldades encontradas foram a falta de referenciais teóricos e aplicações sobre este ramo de atuação, e a adaptação das metodologias de análise.

Por fim, é possível concluir que os riscos ocupacionais estão presentes, tanto nas grandes como em pequenas empresas, e a conscientização sobre tal assunto é muito importante. Por menores que sejam, os riscos sempre existirão e estudalos e tentar reduzi-los é mais apropriado e custa menos para empresa do que tratar futuros problemas causados pela falta de políticas de saúde e segurança do trabalhador. 


\title{
Preliminary risk analysis: case study at a dental prosthesis laboratory
}

\begin{abstract}
Safety and Health at Work are fundamental to execute legislation and work indicators. However, in addition to reducing occurrences, it is important to know causes and risks associated, identifying and analyzing them through specific tools. With this, there are solutions that can exist for many situations. The work performed by this study is important for a Dental Prosthesis Laboratory. To do so, the Preliminary Risk tools and the OWAS method were used along with the company's layout and its production process to identify the returns and draw up a Risk Map. From the development of the research, it may be that occupational hazards are present in the work environment, and the risk of greater recurrence is ergonomic. Finally, it is possible that the risk assessment, presented to the company and later, provides means of reduction, is of great importance for companies and is useful to the employee.
\end{abstract}

KEYWORDS: Occupational risks. Risks identification and analysis. Workplace. 
AMARILLA, R. S. D.; CATAI, R. E.; HOLLEBEN, M. V. Gestão de Riscos: Análise Preliminar de Riscos na Produção de Estruturas Pré-Fabricadas de Concreto. In: CONGRESSO NACIONAL DE EXCELÊNCIA EM GESTÃO, 8, 2012, Rio de Janeiro. Anais... Rio de Janeiro: FIRJAN-RJ, 2012.

BERKENBROCK, P. E.; BASSANI, I. A. Gestão do risco ocupacional: uma ferramenta em favor das organizações e dos colaboradores. Revista Interdisciplinar Científica Aplicada, v.4, n.1, p.43-56, Sem I 2010. Disponível em: < http://rica.unibes.com.br/index.php/rica/article/view/360/318>. Acesso em 25 mai. 2018.

BRASIL. Decreto-lei N 6367, de 19 de outubro de 1976. Diário Oficial da União, Brasília, DF, 21 out. 1976. Disponível em: < http://www.planalto.gov.br/ccivil_03/leis/L6367.htm>. Acesso em 25 mai. 2018. BRASIL. Ministério do Trabalho. Guia de Análise de Acidentes de Trabalho. 2010. Inspeção do Trabalho, 07 de março de 2016. Disponível em: < http://trabalho.gov.br/seguranca-e-saude-no-trabalho/publicacoes-e-manuais>. Acesso em 25 mai. 2018.

BRASIL. Ministério do Trabalho. Portaria MTb $n^{\circ} 871$, de 06 de julho de 2017. NR 09 - Programa de Prevenção de Riscos Ambientais. Diário Oficial da União, Brasília, DF, 07 jul. 2017. Disponível em: < http://trabalho.gov.br/images/Documentos/SST/NR/NR-09.pdf>. Acesso em 28 abr. 2018.

BRASIL. Ministério do Trabalho. Portaria SIT n 13, de 21 de junho de 2007. NR 17 - Ergonomia. Diário Oficial da União, Brasília, DF, 26 jun. 2007. Disponível em: <http://trabalho.gov.br/images/Documentos/SST/NR/NR17.pdf>. Acesso em 28 abr. 2018.

BRASIL. Ministério do Trabalho. Portaria SIT $n^{\circ}$ 247, de 12 de julho de 2011. NR 05 - Comissão Interna de Prevenção de Acidentes. Diário Oficial da União, Brasília, DF, 14 jul. 2011. Disponível em: <http://trabalho.gov.br/images/Documentos/SST/NR/NR5.pdf>. Acesso em 28 abr. 2018.

BRASIL. Ministério do Trabalho. Segurança e Saúde no Trabalho. 2015. Disponível em: <http://trabalho.gov.br/seguranca-e-saude-no-trabalho>. Acesso em: 25 abr. 2018.

CESARO, L. R. Adaptação das Técnicas APR e HAZOP ao Sistema de Gestão de Segurança do Trabalho e Meio Ambiente. 2013. 65 f. Monografia (Especialização) - Curso de Engenharia de Segurança do Trabalho, Departamento 
Acadêmico de Construção Civil, Universidade Tecnológica Federal do Paraná, Curitiba, 2013.

CHAGAS, A. M. R.; SALIM, C. A.; SERVO, L. M. S. Saúde e Segurança no Trabalho no Brasil: Aspectos Institucionais, Sistemas de Informação e Indicadores. 2. ed. São Paulo: Ipea, 2012. 391 p.

DIAS, E. C.; SILVA, T. L. Contribuições da Atenção Primária em Saúde para a implementação da Política Nacional de Saúde e Segurança no Trabalho (PNSST). Revista Brasileira de Saúde Ocupacional, v. 38, n. 127, p. 31-43, jan./jun. 2013. crossref

FBF Sistemas. Software Ergolândia 6.0. Disponível em <http://www.fbfsistemas.com/ergonomia.html>. Acessado em: 25 ago. 2018.

FREITAS, L. C. Manual de Segurança e Saúde do Trabalho. 3. ed. Lisboa: Sílabo, 2016. 723 p.

GIL, A. C. Como Elaborar Projetos de Pesquisa. 5. ed. São Paulo: Atlas, 2010. 200 p.

IIDA, I. Ergonomia: Projeto e Produção. 2. ed. São Paulo: Edgard Blucher, 2005. $340 \mathrm{p}$.

MÁSCULO, F. S.; VIDAL, M. C. Ergonomia: Trabalho Adequado e Eficiente. Rio de Janeiro: Elsevier, 2011. 648 p.

MATTOS, U. A. O.; MÁSCULO, F. S. Higiene e Segurança do Trabalho. Rio de Janeiro: Elsevier, 2011. 408 p.

MATTOS, U. A. O. Mapa de Riscos: o controle da saúde pelos trabalhadores. DEP, 21: 60-74, 1993.

PORTO, M. F. S. Análise de Riscos nos Locais de Trabalho: conhecer para transformar. 2008.

<https://normasregulamentadoras.files.wordpress.com/2008/06/riscos_trabalho .pdf>. Acesso em: 28 abr. 2018.

RODRIGUES, C. Higiene e Segurança do Trabalho: Manual técnico do formando. Braga: Nufec, 2006. 378 p. 
SILVA, N. M. G. Análise de Risco Associada a Prazos de Execução de Obras. 2010. 72 f. Dissertação (Mestrado) - Curso de Engenharia Civil, Faculdade de Engenharia da Universidade do Porto, Porto, 2010. Disponível em: <https://repositorioaberto.up.pt/bitstream/10216/61227/1/000148022.pdf>. Acesso em: 25 maio 2018.

ZAGUINI, T. A. Avaliação das Metodologias de Gerenciamento de Riscos Ambientais e de Segurança de Incêndio em uma Fábrica de Pneus no Rio de Janeiro - RJ. 2012. 105 f. Dissertação (Mestrado) - Curso de Engenharia Ambiental, Universidade Federal do Rio de Janeiro Escola Politécnica \& Escola de Química Programa de Engenharia Ambiental, Rio de Janeiro, 2012. Disponível em: <http://dissertacoes.poli.ufrj.br/dissertacoes/dissertpoli421.pdf>. Acesso em: 25 maio 2018.

VILAS BOAS, H.G. et al. Análise preliminar de riscos: estudo de caso em um laboratório de prótese odontológica. R. Gest. Industr., Ponta Grossa, v. 16, n. 2, p. 234-246, Abr./Jun. 2020. Disponível em: https://periodicos.utfpr.edu.br/revistagi .

Correspondência:

Higor Guilherme Vilas Boas

Endereço completo para correspondência (bairro, cidade, estado, país e CEP): Av. Colombo, 5790, Bloco 19 Maringá,Paraná, Brasil.

Direito autoral: Este artigo está licenciado sob os termos da Licença Creative Commons-Atribuição 4.0

Internacional.

\section{(c) (i)}

